\title{
Three Cases of Occult Pneumococcal Bacteremia
}

\author{
Kousaku MATSUBARA, Kei SUZUKI, Ying Wei LIN and Shigeru OHTA \\ Department of Pediatrics, Matsue Red Cross Hospital \\ (Received: Jun 11, 1990) \\ (Accepted: August 6, 1990)
}

Key words: Occult bacteremia, Streptococcus pneumoniae

\section{Introduction}

Streptococcus pneumoniae (S. pneumoniae) is the most frequent bacterial cause of otitis media and pneumonia and the third most common cause of meningitis in childhood ${ }^{1}$. It has been recently reported that this organism is also the cause of occult bacteremia in febrile children especially those under 2 years of age ${ }^{2) \sigma 6}$. "Occult" bacteremia means bacteremia occuring in the febrile children without any apparent foci of infection or with trivial infections such as upper respiratory tract infection (URTI). Bacteremia is distinguished from sepsis by the absence of evidence of organ failures such as cardiovascular failure. Few cases of occult bacteremia have been reported in Japan. We present here three cases of occlut bacteremia and discuss how to detect the children with occult bacteremia among febrile outpatients and how to prevent the subsequent complications.

Case 1

A 9-month-old previously healthy boy was brought to our hospital because of fever and ill temper at 1 o'clock. The temperature was $40^{\circ} \mathrm{C}$, the respiration rate was $60 / \mathrm{min}$, and the pulse was $180 / \mathrm{min}$. Physical examination revealed a slightly injected throat. No moist rales were detected in the lung fields. Tympanic membrane was not injected. A chest roentogenogram showed no infiltration. Peripheral blood was obtained for a complete blood count and for blood cultures. The white blood cell (WBC) count was $14,800 / \mathrm{mm}^{3}$. We diagnosed him as having URTI. We administered a ceftizoxime suppository and reexamined him in the outpatient clinic before noon on that day. At the second visit, the tempearture was $38^{\circ} \mathrm{C}$ and tachypnea had disappeared. Physical examination again revealed no apparent focus of infection. We prescribed oral cefaclor. Two days after the initial visit, the blood culture was shown to be positive for S. pneumoniae, and the patient was reviewed again the next day. He had neither fever, tachypnea, nor irritability and his appetite was good, so we did'nt perform any further treatment or studies.

Case 2

A 1-year-old girl was admitted to our hospital because of a generalized tonic-clonic convulsion with fever. She had had no previous episodes of convulsion and no family members had epilepsy. The convulsion continued for 2 minutes without lateralization. She had suffered from cough and rhinorrea for the previous 2 days. On admission, the temperature was $39.2^{\circ} \mathrm{C}$ and her conciousness was clear. Physical examination revealed only a slightly injected throat. No abnormal neurological findings were shown. The WBC was $20,300 / \mathrm{mm}^{3}$ with $51 \%$ neutrophils and the C-reactive protein (CRP) was $0.4 \mathrm{mg} / \mathrm{dl}$. Cerebrospinal fluid showed no pleocytosis and normal levels of glucose and protein. Her electroencephalogram was also normal. We diagnosed her as having a simple febrile convulsion associated with URTI. She was treated with antipyreitcs and erythromycin. On the 2nd hospital day, the cultures of blood and throat swab

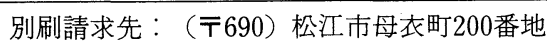

松江赤十字病院小览科松原康策

平成 3 年 2 月 20 日 
Table Characteristics of the patients with pneumococcal bacteremia

\begin{tabular}{|c|c|c|c|c|c|c|c|}
\hline \multirow{2}{*}{$\begin{array}{c}\text { Case } \\
\text { number }\end{array}$} & \multicolumn{2}{|c|}{ Patient } & \multirow{2}{*}{$\begin{array}{l}\text { Peak } \\
\text { fever } \\
\left({ }^{\circ} \mathrm{C}\right)\end{array}$} & \multirow{2}{*}{$\begin{array}{l}\text { White blood } \\
\text { cell count } \\
\left(\times 10^{3} / \mathrm{mm}^{3}\right)\end{array}$} & \multirow{2}{*}{$\begin{array}{l}\text { Initial } \\
\text { diagnosis }\end{array}$} & \multirow{2}{*}{$\begin{array}{l}\text { Antibiotic } \\
\text { treatment }\end{array}$} & \multirow{2}{*}{$\begin{array}{l}\text { Day on which } \\
\text { blood culture } \\
\text { was positive }\end{array}$} \\
\hline & $\begin{array}{c}\text { Age } \\
\text { (month) }\end{array}$ & Sex & & & & & \\
\hline 1 & 9 & $\mathrm{M}$ & 40.0 & 14.8 & URTI & $\begin{array}{l}\text { suppository, day } 1 \\
\text { oral, day } 2\end{array}$ & 3 \\
\hline 2 & 12 & $\mathrm{~F}$ & 39.2 & 20.3 & $\begin{array}{l}\text { febrile } \\
\text { convulsion } \\
\text { with URTI }\end{array}$ & oral, day 1 & 3 \\
\hline 3 & 9 & $\mathrm{~F}$ & 39.0 & 13.4 & FUO & $\begin{array}{c}\text { oral, day } 2 \\
\text { intravenous, day } 9\end{array}$ & 11 \\
\hline
\end{tabular}

URTI : Upper respiratory tract infection FUO : Fever of unknown origin

obtained on admission became positive for S. pneumoniae. However, she had already become afebrile, so we performed no additional treatment.

Case 3

A 9-month-old girl was admitted to our hospital because of fever of unknown origin persisiting for 8 days. She had suffered mild rhinorrea and had been treated with oral antibiotics and antibechies. On admission, the temperature was $39^{\circ} \mathrm{C}$ but she appeared well. Physical examination revealed only a slightly injected throat. The WBC was $13,4000 / \mathrm{mm}^{3}$ with $36 \%$ segmented neutrophils and $21 \%$ band neutrophils, and the CRP was $7.7 \mathrm{mg} / \mathrm{dl}$. To determine the focus of the infection, the antibiotic treatment was discontinued for 24 hours and, thereafter, cultures of blood, throat swab, urine, and stool were obtained. Then cefzoname was administered intravenously. S. pneumoniae was isolated from blood on 2 days later, when she was afebrile. On the fifth hospital day, the otomycroscopic examination showed a trivially injected tympanic membrane. It was questionable whether this had been the focus of infection. Antibiotic treatment was continued until the CRP became negative. She was discharged on the 7 th hospital day without any sequelae.

\section{Discussion}

S. pneumoniae is the most frequent bacterial cause of otitis media and pneumonia in childhood ${ }^{1}$. It has been recently reported that this organism is also the cause of occult becteremia in febrile children especially those under 2 years of age ${ }^{2) \sim 6)}$. Because a small number of the affected children develop the serious complications such as menigitis, how to detect occult bacteremia have been also earnestly discussed $^{2) \sim 6)}$. Among children with occult bacteremia, about $85 \%$ of positive blood cultures yield encapsulated bacteria, including $S$. pneumoniae and Hemophilus influenzae $(H \text {. influenzae })^{6)}$. Teele et al. ${ }^{2)}$ reported that the majority of such bacteremia is caused by $S$. pneumoniae (approximately 65\%) with $H$. influenzae accounting in about 25\%, and other bacteria for the rest. In Japan, few cases of occult bacteremia have been reported ${ }^{78)}$. We suppose that this is firstly because blood cultures are seldom obtained at the first visit, secondly because antibiotics are widely prescribed for febrile outpatients, and thirdly because this clinical entity is not enough known by physicians. Since Besly ${ }^{9}$ first described it in 1967, there have been many reports in the United States ${ }^{244) 66}$. Nevertheless in other countries including Britain ${ }^{3)}$ and Japan ${ }^{78)}$, this disease is not so common as in the US. The frequency of the occult bacteremia may thus have regional differences.

To diagnose the occult bacteremia is difficult because of the lack of the specific physical findings. A number of physical and laboratory findings have been reported to increase the risk of bacteremia. Teele $e t$ $a l .{ }^{2)}$ listed the risk factors for occult bacteremia, including an age between 6 to 24 months, a fever of over $38.9^{\circ} \mathrm{C}$, and a WBC of over $15,000 / \mathrm{mm}^{3}$. In children in these features, they reported the frequency of occult 
bacteremia to be about $4 \%$. Many reports have noted the significance of these three factors ${ }^{4) ~ 6)}$. In our cases, these three factors were also positive except for the WBC of case 1 and case 3 . Other additional risk factors, including a raised CRP and erythrocyte sedimentation rate were reported ${ }^{25) 10}{ }^{2}$. Nelson ${ }^{11}$ used clinical observation scores while McCarthy et al. ${ }^{12)}$ investigated the physician's assesment of activity level, feeding, and sleeping patterns, etc. McIntyre et al. ${ }^{3)}$ reported that 10 out of 29 occult bacteremia cases had been admitted because of a simple febrile convulsion initially. They suggested that occult bacteremia might be an important cause of febrile convulsions, especially under 4 years of age. In fact, a febrile convulsion was associated with bacteremia in our case 2 . The association of febrile convulsions and occult bacteremia should be further evaluated in a larger study. To detect the children with occult becteremia, we believe that it is important to use the combination of these physical and laboratory risk factors and to obtain blood culture if occult bacteremia is suspected.

There remains a controversy regarding whether all children with occult bacteremia should be treated or not. In many cases occult bacteremia resolved self-limitedly, and in only a small number of patients develop subsequent meningitis or other serious infections ${ }^{2 / 6)}$. The risk of the these complications remains uncertain. S. pneumoniae isolated from our three cases were very sensitive to used antibiotics by disc method (minimum inhibitory concentrations were not examined). However, case 1 and case 2 may have improved spontaneously. Teele et al.$^{2)}$ recommended that the febrile children at risk should be treated with antibiotics. But in their report, 2 of the 51 children not treated at the first visit developed subsequent meningitis, while 2 of the 47 given treatment also developed meningitis. Recent data also suggest that oral antibiotic therapy may be ineffective in preventing infectious sequelae of bacteremia ${ }^{13)}$. We believe that regardless of whether antibiotics are given or not, such children should be carefully observed either at home or in the hospital, and should be reexamined until they become afebrile.

There is a general agreement that children with asplenia or immunodeficiency must be treated with antibiotics soon after they develop fever. Pneumococcal bacteremia in these high-risk children may progress to serious complications. Vaccine against pneumococcal polysaccarides, now available, should be indicated for such children. Oguri ${ }^{14)}$ examined the drug-susceptibilities of $S$. pneumoniae obtained from clinical specimens and reported that approximately 40 to $70 \%$ of the strains were resistant against tetracycline and chloramphenicol, and that $0.01 \%$ were resistant against $\beta$-lactam antibiotics. Because $\beta$-lactam-resistant strains were usually isolated from the patients under treatment with $\beta$-lactam antibiotics ${ }^{14}$, we think that even now penicillins and cephems are effective to $S$. pneumoniea isolated from the children at the first visit to outpatient clinic.

\section{References}

1) Behrman, R.E. \& Vaughan, V.C.: Nelson's Textbook of Pediatrics (13th ed). p.584-586, Saunders, Philadelphia, 1987.

2) Teele, D.W., Marshall, R. \& Klein, J.O.: Unsuspected bacteremia in young children, a common and important problem. Pediatr. Clin. North Am. 26: 773-784, 1979.

3) McIntyre, P., Kennnedy, R. \& Harris, F.: Occult pneumococcal bacteremia and febrile convulsions. Br. Med. J. 286: 203-206, 1983.

4) Teele, D.W., Pelton, S.I., Grant, M.J.A., Herskowitz, J., Rosen, DJ., Allen, C.E., Wimmr, R.S. \& Klein, J.O.: Bacteremia in febrile children under 2 years of age: Results of cultures of blood of 600 consecutive febrile children seen in a "walk-in" clinic. J. Pediatr. 87: 227-230, 1975.

5) McCarthy, P.L., Grundy, G.W., Spiesel, S.Z. \& Dolan, T.F.: Bacteremia in children: An outpatient clinical review.J. Pediatr. 57: 861-868, 1976.

6) McLellan, D. \& Giebink, S.: Perspectives on occlut bacteremia in children. J. Pediatr. 109: 1-8, 1986.

7) Ishiguro, N., Konno, N., Endoh, M., Yamada, Y. \& Togashi, T.: A case of primary pneumococcal bacteremia (in Japanese). Jap. J. Pediatr. 41: 607-610, 1988.

8) Sumimoto, S., Kawai, M., Kasajima, Y. \& Torata, H.: A case of primary pneumococcal bacteremia (in Japanese). Jap. 
J. Pediatr. 43: 244-247, 1990.

9) Belsey, M.A.: Pneumococcal bacteremia: a report of three cases. Am. J. Dis. Child. 119: 12-17, 1967.

10) McCarthy, P.L., Jekel, J.F. \& Dolan, T.F.: Comparison of acute phase reactants in pediatric patients with fever. Pediatrics 62: 716-720, 1978.

11) Nelson, K.G.: An index of severity for acute pediatric illness. Am. J. Public Health 70: 804-807, 1980.

12) McCarthy, P.L., Jekel, J.F., Stashwick, C.A., Spiesel, S.Z., Dolan, T.F., Sharpe, M.R., Forsyth, B.W., Boran, M.A., Fink, H.D., Rosenbloom, M.L., Etkin, T. \& Zelson, J.H.: Further definition of history and observation variables in assessing febrile children. Pediatrcs 67: 687-693, 1981.

13) Jaffe, D.M., Tanz, R.R., Davis, A.T., Henretig, F. \& Fleisher, G.: Antibiotic administration to treat possible occult bacteremia. N. Engl. J. Med. 317: 1175-80, 1987.

14) Oguri, T.: Clinical and bateriological studies of Streptococcus pneumoniae. Yearly changes in isolation frequencies from clinical specimens, sero-type distributions and drug-susceptibilities, especially those of $\beta$-lactam-resistant strains (in Japanese). Jap. J. Antibiot. 39: 783-806, 1986.

潜在性肺炎双球菌菌血症の 3 例

松原 康策 鈴木 圭江赤十字病院小坚科

潜在性肺炎双球菌菌血症（occult pneumococcal bacteremia）の 3 症例を報告した。 3 例とも 臨床症状だけでは菌血症の存在は推測できず, 初 診時の診断は，それぞれ急性上気道炎，急性上気 道炎に合併した熱性㾏孪, 不明熱であった、3 例 とも年齢は 2 歳以下, 体温は $39^{\circ} \mathrm{C}$ 以上, 白血球増 多が認められ白血球数はそれぞれ $14,800 / \mathrm{mm}^{3}$,
$20,300 / \mathrm{mm}^{3}, 13,400 / \mathrm{mm}^{3}$ であった. 3 症例とも 抗生物質の投与により合併症なく治癒した。本症 の報告はわが国では稀である、発熱を主訴とする 外来患者に対して, 年齢, 発熱の程度, 白血球数 などの危険因子を組合わせ，本症が疑われる場合 には血液培養を施行することが肝要と考兄られ た. 